\title{
PROCEDURAL ASPECTS REGARDING INTERNATIONAL ARBITRATION
}

\author{
Berlingher Remus Daniel \\ "Vasile Goldis" Western University of Arad, Faculty of Law \\ berlingherdaniel@yahoo.com \\ Cret Daniela Cristina \\ "Vasile Goldis" Western University of Arad, Faculty of Law
}

(Received April 2015; accepted June 2015)

\begin{abstract}
Socio-economic changes have led to significant changes with regard to the institutions regulated by the 1865 Code of Civil Procedure and other laws, such as Law no. $105 / 1992$ on the regulation of private international law. Among the institutions that have undergone these reconfigurations in the regulation of the Code of Civil Procedure, which entered into force in 2013, one that stands out is arbitration. Our study will analyze the main aspects of private international law arbitration: arbitration agreement, the arbitral tribunal, the proceedings in the matter, as well as the recognition and enforcement of foreign arbitral awards.
\end{abstract}

Keywords: arbitral tribunal, foreign element, arbitral award, lex fori

\section{Definition and legal nature}

Arbitration is the settlement of a dispute by a person or by a body established by agreement or by international conventions, thereby escaping the jurisdiction of the courts (D. Lupaşcu, D. Ungureanu, 2012, pp. 315).

Analyzing the rules of civil procedure shows the mixed nature of arbitration: contractual, due to its source, and jurisdictional through the procedure and decision made by the arbitrators (O. Ungureanu, C. Jugastru, A. Circa, 2008).

Depending on the legal framework within which arbitration takes place in doctrine and in legislation in the mater, a differentiation is made between domestic law arbitration if the legal dispute between the parties does not contain any foreign element, and private international law arbitration, if the dispute under judgment derives from a legal fact of private law with a foreign element.

Private international law arbitration was established by Law no. 105/1992 on the regulation of private international law relations, repealed by the new Code of Civil Procedure, now governed by the provisions of Book VII of the Code of Civil Procedure, provisions governing international civil proceedings, i.e. proceedings of private law with a foreign element. The phrase "private law proceedings" shall take into account any civil litigation, except for those that are subject to criminal law. A 
Berlingher, R.D., Cret, D.C., (2015)

Procedural aspects regarding international arbitration

foreign element is a complex fact that can target the parts, the scope or the content of a legal relation.

The provisions of Book VII are incidental to private law proceedings with foreign elements if international treaties to which Romania is a party, through European Union law or special laws, do not provide otherwise.

\section{The arbitration agreement}

The arbitration agreement is the understanding by which the parties agree that a particular dispute or certain disputes arising or which may arise between them be resolved by individuals - arbitrators - appointed according to their understanding (I. Deleanu, 2007, pp. 337).

The arbitration agreement is subject to conditions of substance and form. The basic contract and the arbitration agreement are independent or autonomous from one another, with the following consequences resulting from their autonomous character:

- Resolution or termination of the basic contract, or the legal operation, does not entail the repeal of the arbitration agreement in this way; the nullity of the basic contract does not affect the validity of the arbitration clause, which is independent of that in the basic contract in which it was inserted.

- The law applied to arbitration agreement may differ from the law of the basic contract.

The parties may agree that the arbitration designated to settle the litigation (dispute) be organized by a permanent institution or third person (art. 545 of the Code of Civil Procedure). However, through an arbitration agreement relating to international arbitration, the parties may agree that the dispute be settled by an arbitral jurisdiction in Romania or in another state.

Under the provisions of art. 549 para. (1) of the Code of Civil Procedure, there may be two forms of arbitration agreement. Therefore, the parties may resort to the arbitration procedure in two ways:

- by way of arbitration clause in the main contract or established in a separate agreement, to which the main contract makes reference;

- by way of the arbitration agreement, called compromise, which may take the form of an independent agreement.

The arbitration clause is a provision contained in a contract whereby the parties agree that any disputes will arise in connection with this contract shall be settled by arbitration; the arbitration clause is, therefore, a contract within another contract, resulting in two different contracts: the main (basic) contract and the arbitration clause.

The arbitration agreement or compromise is the agreement between the parties whereby they agree that a dispute which might arise or has arisen between them be 
Berlingher, R.D., Cret, D.C., (2015)

Procedural aspects regarding international arbitration

referred for settlement to arbitration courts, thereby escaping the jurisdiction of judicial courts.

\subsection{Validity conditions of the arbitration agreement}

The validity of the arbitration agreement is subject to the following conditions of substance and form:

Conditions of substance: To take effect, both the arbitration clause and the compromise must, in principle, meet the substantive conditions of validity set out by the internal substantive law provisions of the Civil Code, namely: consent, the parties' capacity, a specific object and a lawful cause. Among them, only the capacity and object feature some exceptions from the common law regime (I. Macovei, 2011, pp. 283). Thus, the parties' capacity to conclude an arbitration agreement according to the rule on conflict regarding capacity is subject to national law. The object of the arbitration agreement consists of the obligation of the parties to submit the dispute to settlement by arbitration proceedings. To be the object of an arbitration agreement, the dispute between the parties must be arbitral. As an exception, the regulations stipulated in art. 542 para. (1) of the Code of Civil Procedure remove from the object of the arbitration agreement any disputes concerning marital status, the individuals' capacity, inheritance, family relations, as well as any rights of which the parties may not freely dispose.

Conditions of form: The arbitration agreement, both concluded in the form of an arbitration clause and concluded in the form of compromise must be in writing, under penalty of nullity.

According to art. 1112 par. (1) of the Code of Civil Procedure, the arbitration agreement shall be concluded validly in writing by registered document, telegram, telex, facsimile, electronic mail or any other means of communication allowing to establish the evidence by text.

However, according to Art. 551 para. (1) of the Code of Civil Procedure on compromise, the latter agreement must include, under penalty of nullity, the object of dispute and the names of the arbitrators or the method of their appointment in the case of ad hoc arbitration, while in the case of institutionalized arbitration, unless the parties did not choose the arbitrators, nor did they determine their designation, it will be done according to the rules of procedure of the institution of arbitration.

\subsection{The effects of the arbitration agreement}

The conclusion of the arbitration agreement in the form of an arbitration clause or a compromise produces the following effects: 
Berlingher, R.D., Cret, D.C., (2015)

Procedural aspects regarding international arbitration

- With regard to the parties to the dispute, the arbitration agreement, as any legally binding agreement, has the force of law between the contracting parties. Consequently, the parties shall:

a. submit their dispute to be settled by the arbitral jurisdiction designated by the arbitration agreement;

b. to submit to the judgment of the arbitral jurisdiction.

- In relation to the seized court, the arbitration agreement, in principle, removes the jurisdiction of judicial courts in settling the dispute which has its origin in the main contract or the basic legal operation.

The jurisdiction of the judicial court in settling the dispute with which it was vested is, however, excluded under the following conditions:

- If the plea of lack of jurisdiction of attribution invoked by one of the parties to the dispute has been admitted, the court, noting the existence of the arbitration agreement, shall be declared non-competent, declining its jurisdiction in favor of the competent domestic arbitral jurisdiction. In turn, the arbitral jurisdiction will decide on its competence in settling the dispute in a ruling that can only be abrogated by an action for annulment. The conflict of competence which may arise between the initially seized court and the arbitral jurisdiction shall be resolved by a higher court.

- The plea of lack of jurisdiction will be rejected, and the dispute will be retained for settlement under the following circumstances referred to expressly and exhaustively through art. 554 para. (2) of the Code of Civil Procedure:

a. the defendant has filed defenses in the substance, without any reservation based on the arbitration agreement;

b. the arbitration agreement is invalid or inoperative;

c. the arbitral tribunal cannot be established for reasons that are clearly attributable to the defendant in the arbitration.

\subsection{The law applicable to the arbitration agreement}

The arbitration agreement is valid in terms of substantive requirements if it meets the conditions imposed by one of the following laws [art. 1112 par. (2) Code of Civil Procedure]:

a. the law determined by the parties (lex voluntatis);

b. the law governing the object of dispute;

c. the law applicable to the contract containing the arbitration clause;

d. Romanian law.

If the parties have not determined the law applicable to the arbitration agreement, it will be governed by the law of the country in which the arbitral award is to be given (art. V para.1 let. a of the New York Convention; art.VI para. 2 let. b of the Geneva Convention). For situations where it is not possible to predict which 
Berlingher, R.D., Cret, D.C., (2015)

Procedural aspects regarding international arbitration

country the award will be given in, the competent law in virtue of conflict rules of the seized authority (art.VI para. 2 let. c of the Geneva Convention) will apply.

\section{The arbitral tribunal}

The arbitration may be entrusted to one or more persons, designated by the parties or in accordance with the provisions of the arbitration agreement to judge a dispute and to deliver a final and binding decision for on them. The parties may also agree that the arbitration be organized by a permanent arbitration institution or a third person. The sole arbitrator or the entirety of vested arbitrators constitutes the arbitral tribunal (I. Macovei, 2011, pp. 285).

\subsection{Appointment, dismissal and replacement of arbitrators}

According to art. 1113 para. 1 of the Code of Civil Procedure, the appointment, dismissal and replacement of arbitrators is carried out:

- according to the arbitration agreement;

- according to the conditions established by the parties after the conclusion of the arbitration agreement;

- in absence thereof, the interested party may request the arbitration tribunal from the seat of arbitration to do so.

In cases where the parties choose the law applicable to the arbitration proceedings, they must comply with its imperative provisions referring to the establishment of the arbitral tribunal (I. Deleanu, V. Mitea, S. Deleanu, 2013, p. 591).

\subsection{Challenging arbitrators}

The arbitrator may be challenged if:

- he does not have the qualifications established by the parties;

- when there is a cause for challenge among the ones provided for by the rules of arbitration procedure adopted by the parties or, failing that, by the arbitrators;

- when the circumstances induce a legitimate doubt about his/her independence and impartiality [art. 1113 para. (2) of Code of Civil Procedure].

This legal provision, by which the arbitrator may be challenged, outlines the possibility of the parties to establish certain requirements referring to the qualifications of arbitrators (e.g. for the presiding arbitrator to be legally qualified). A party may not challenge an arbitrator s/he has appointed or in whose appointment $\mathrm{s} / \mathrm{he}$ has contributed except for reasons of which $\mathrm{s} / \mathrm{he}$ became aware after the appointment. In this case, the arbitral tribunal and the other party should be notified without delay of the reason for challenge [art. 1113 par. (3) Code of Civil Procedure]. 
Berlingher, R.D., Cret, D.C., (2015)

Procedural aspects regarding international arbitration

If the parties have not determined the challenge procedure, the arbitral tribunal from the seat of arbitration shall rule on the challenge by final judgment [art. 1113 par. (4) Code of Civil Procedure].

\section{Arbitration proceedings in private international law}

In accordance with art. 1114 para. (1) of the Code of Civil Procedure, the parties may determine the arbitration proceedings directly or by reference to the regulations of an institution of arbitration, or may submit it to a procedural law of their choice. If the parties have not proceeded as provided in para. (1), the arbitral tribunal shall determine the procedure in one of the ways provided at para. (1) (T. Chiuariu, R. Giurea, 2013, pp. 136). The legal regulation provided at para. 3 stipulates that whatever the arbitration proceedings established, the arbitral tribunal must guarantee equality of parties and their right to be heard in adversarial proceedings. In international arbitration, the duration of terms set in Book IV (I. Les, 2013) is doubled.

In the arbitration of private international law which operates in Romania or under Romanian law, court proceedings are conducted primarily under the rules of procedure applicable to domestic arbitration, with the following features considering: the establishment of the arbitral tribunal, the proceedings and arbitration costs.

\subsection{The establishment of the arbitral tribunal}

The arbitral tribunal in private international law will always consist of an odd number of members [Art. 556 para. (1) of the Code of Civil Procedure]. If the parties have not determined the number of arbitrators, the dispute shall be settled by three arbitrators, one appointed by each party and the third - the presiding arbitrator - appointed by the two arbitrators. If there are multiple claimants or several defendants, the parties that have joint interests shall appoint a sole arbitrator.

\subsection{Proceedings}

The dispute is examined in open court. Notwithstanding this rule, at the request of either party or of its own motion, the arbitral panel may decide that the dispute be discussed in closed court. The closed meeting can only be attended by the litigants or their representatives, their advisors and any other persons who have been summoned (G. Mihai, 2013, pp. 150).

According to art. 1115 of the Code of Civil Procedure, the proceedings of the dispute before the arbitral tribunal shall be conducted in the language determined by the arbitration agreement or, nothing was provided in this regard or a subsequent agreement did not intervene, in the language of the contract from which 
Berlingher, R.D., Cret, D.C., (2015)

Procedural aspects regarding international arbitration

the dispute arose or in an international language established by the arbitral tribunal (I. Deleanu, V. Mitea, S. Deleanu, 2013, pp. 596). If one one of the parties does not speak the language in which the proceedings are conducted, at his/her request and expense, the arbitral tribunal may provide an interpreter, who can be chosen by the parties themselves (V. M. Ciobanu, T. C. Briciu, C. C. Dinu, 2013, pp. 608).

Likewise, the parties may participate in debates with their own translator.

\subsection{Arbitration costs}

According to art. 1121 para. 1 of the Code of Civil Procedure, arbitrators' fees and travel expenses are borne by the party that appointed them, unless the parties have agreed otherwise (T. Chiuariu, R. Giurea, 2013, pp. 142). In the case of a sole arbitrator or presiding arbitrator, these expenses are borne by the parties in equal shares.

\section{Recognition and enforcement of foreign arbitral decisions}

\subsection{The concept, contents, effects and abrogation of a foreign arbitral award} In the terms of the civil procedural law, a foreign arbitral award refers to any arbitral award of domestic or international law rendered in a foreign country and which is not qualified as a national judgment in Romania (art. 1123 of the Code of Civil Procedure). Moreover, the doctrine considers that the arbitral award rendered in one state and invoked in another state is, for the latter, a foreign arbitral award (I. P. Filipescu, A. I. Filipescu, pp. 462-468).

A foreign arbitral award must be in writing and must be reasoned, dated and signed by all judges. It comprises the same elements as a judgment: the introductory part, the pleas in fact and in law and the operative part, but translated into the specificities of arbitral proceedings.

As regards the effects of foreign arbitral award, in conjunction with the provisions of art. 1120 and art. 606 of the Code of Civil Procedure, we consider that they are the same as those generated by any judgment: binding character, divestment of the arbitral tribunal, res judicata power, enforceability, probative value, and prescription.

The procedural means provided by both the old and the new Romanian Code of Civil Procedure to abrogate the arbitral award is the action for annulment.

\subsection{The demands of recognition and enforcement of a foreign arbitration award}

The provisions of art. 1124 of the Code of Civil Procedure establish two essential conditions for the recognition and enforcement of foreign arbitral awards. The first condition refers to the arbitrability of the dispute, and that requirement is judged by 
the law of the court requested to approve the recognition or enforcement (I. Leş, 2013). The second requirement is keeping public order of Romanian private international law. This condition is also assed according to Romanian law.

For the recognition and enforcement of a foreign arbitral award, an application must be submitted, addressed to the court, in accordance with art. 95 pt. 1 of Code of Civil Procedure. In the area of territorial jurisdiction, jurisdiction lies with the court whose district contains the residence or, where applicable, the offices of the person against whom that arbitral award is rendered. If this tribunal cannot be established, the jurisdiction will be assigned to the Tribunal of Bucharest.

The party invoking a foreign arbitral award may only require recognition to operate res judicata or, if not fulfilled voluntarily, the approval of enforcement on the Romanian territory. Under the terms of the civil procedural law, the recognition of a foreign arbitral award may also be requested indirectly, through another trial.

Documents to be attached to the application for recognition or approval of enforcement are the foreign arbitral award and the arbitration agreement. These documents must be submitted in original or in copy and are subject to superlegalization, like foreign judgments. If these documents are not written in Romanian, the applicant must also submit their certified translation into Romanian. Unlike the circumstances set out by procedural rules for the recognition or approval of enforcement of a foreign judgment, the grounds for refusing the recognition or enforcement of foreign arbitral awards have regard to respect for fundamental principles of the legal system in the requested State or the validity or limits of the arbitration agreement or the establishment of the arbitral tribunal (I. Leş, 2013).

On the application for recognition or enforcement of a foreign arbitral award, the tribunal pronounces itself by decision rendered by summoning the parties or without summoning the parties, if the decision shows that the defendant has agreed to allow the action. Against that decision, an appeal may be exercised by the interested party.

The provisions of art. 1131 of the Code of Civil Procedure enshrines in Romania the probative value of foreign arbitral awards rendered by a competent arbitral tribunal on factual situations that they ascertain.

\section{Conclusions}

Arbitration is an alternative jurisdiction of private character, being useful to parties in settling disputes between them.

In conducting international arbitral proceedings, the essential principle is the principle of autonomy of will of the parties, under which they may establish, by arbitration agreement, the rules of procedure applicable to arbitration or may empower judges to determine these rules. 
Berlingher, R.D., Cret, D.C., (2015)

Procedural aspects regarding international arbitration

Arbitration in private international law has certain common features with arbitration in domestic law, such as those relating to the effects of a foreign arbitral award, its abrogation by action for annulment, but also certain features concerning the recognition and enforcement of foreign arbitral awards in Romania, features determined by the international nature of the dispute.

We consider that the procedural rules in matters of arbitration in private international law are clear and superior to the regulation of Law no. 105/1992, but some remedies may be made thereto. Thus, given that the second condition for the effectiveness of a foreign arbitral award concerns respecting public order in Romanian private international law, we propose de lege ferenda that the grounds for refusing recognition or enforcement of foreign arbitral awards include the violation of public order.

\section{References:}

T. Chiuariu, R. Giurea, 2013, Arbitraj intern si international, Editura Universul Juridic, Bucuresti, 2012.

O. Ungureanu, C. Jugastru, A. Circa, Manual de drept international privat, Editura Hamangiu, Bucuresti, 2008, p. 273.

I. Deleanu, V. Mitea, S. Deleanu, 2013, Noul Cod de Procedura civila. Comentarii pe articole, vol. II, Editura Universul Juridic, Bucuresti.

V. M. Ciobanu, T. C. Briciu, C. C. Dinu, Drept procesual civil. Drept executional civil. Arbitraj. Drept notarial, Editura National, Bucuresti, 2013.

D. Lupascu, D. Ungureanu, Drept international privat, Editura Universul Juridic, Bucuresti, 2012.

G. Mihai, 2013, Arbitrajul international si efectele hotararilor arbitrale straine, Editura Universul Juridic, Bucuresti.

I. Les, Noul Cod de procedura civila Comentariu pe articole. Art. 1-1133, editia 1, Editura C. H. Beck, Bucuresti, 2013, note under art. 567.

Cret Daniela-Cristina, Dumiter Florin Cornel, Some considerations regarding the Ad-Hoc Internal Arbitration Procedure in the new Code of Civil Procedure, Studia Universitatis "Vasile Goldis" Arad, Seria Stiinte economice, 2013, vol. 23, nr. 4, p. 150-167.

I. Bacanu, Controlul judecatoresc asupra actiunii arbitrale, Editura Lumina Lex, Bucureşti, 2005, p. 22-33. 